\title{
Nutritional Evaluation of Adinandra Nitida Leaves
}

\author{
Gang $\mathrm{Li}^{\mathrm{a}}$, Xiaohong Ge ${ }^{\mathrm{b}}$, Benguo Liu ${ }^{\mathrm{c}}$, Changzhong Liu ${ }^{\mathrm{d}}$ \\ ${ }^{a, b, c}$ School of Food Science, Henan Institute of Science and Technology, Xinxiang 453003, China \\ ${ }^{d}$ School of Animal Science, Henan Institute of Science and Technology, Xinxiang 453003, China
}

\begin{abstract}
In this study, the nutritional evaluation of Adinandra nitida leaves was investigated. It was found that Adinandra nitida leaves were rich in necessary amino acids and unsaturated fatty acids. The content of the main flavonoid (camellianin A) was as high as $27.57 \pm 0.92 \%$. These results proved the high nutritional value of Adinandra nitida leaves. It has great commercial interest in the food and phyto-pharmaceutical market.
\end{abstract}

Index Terms: Adinandra nitida; nutrition; flavonoid

(C) 2011 Published by MECS Publisher. Selection and/or peer review under responsibility of the Research Association of Modern Education and Computer Science.

\section{Introduction}

Adinandra nitida is a kind of particular wild plant in South China. Its leaves have been consumed as health tea (Shiyacha) and herbal medicine for hundreds years, which is reported to have many curative effects, such as reducing blood pressure, antibacterial, antitumor, analgesic etc [1-3]. Today, Adinandra nitida has been successfully cultivated in Guagnxi province, China. The objective of this study work was to evaluate the nutritional value of Adinandra nitida leaves.

\section{Materials and Methods}

\subsection{Materials and Chemicals}

Leaves of Adinandra nitida (2006 spring production, moisture content $9.3 \%$ ) for this study were purchased in Laibin, China. Free Amino acids and Fatty acid methyl esters used as standards were from Sigma Chemicals Co. Other chemical were of analytical grade.

* Corresponding author.

| E-mail address: ${ }^{\mathrm{a}}$ I7760925@163.com; ${ }^{\mathrm{C} Z z g c l b g @ 126 . c o m}$ 


\subsection{Crude Fat and Protein Analysis}

The crude fat and crude protein contents of dried samples were analyzed using the standard AOAC methods (Firestone, 1998), and the compositions were denoted by percentage on dry basis.

\subsection{Analysis of Fatty Acid Composition}

Free amino acid composition was determined with an Amino Acid Analyzer (Waters M510, USA). The different amino acids recovered were presented as $\mathrm{g} / 100 \mathrm{~g}$ dry basis. The $0.5 \mathrm{~g}$ of the sample was soaked in 10 $\mathrm{mL}$ of de-ionized water, and then sonicated for $15 \mathrm{~min}$. The resulting mixture was then centrifuged at 10000 $\mathrm{rpm} / \mathrm{min}$ for $15 \mathrm{~min}$. Determination was obtained by pre-column derivation of the sample with phenyl isothiocyanate and separating the corresponding derivatives with RP-HPLC on a PICO.TAG $\mathrm{NH}_{2}$ analytical column at $38^{\circ} \mathrm{C}$ and UV detection $(254 \mathrm{~nm})$.

A gas chromatograph (GC) (HP5890) equipped with a flame ionization detector (FID) and a HP-Innowax capillary column $(30 \mathrm{~m} \times 0.25 \mu \mathrm{m})$. The column, injector, and detector temperatures were set at 190,230 , and $230{ }^{\circ} \mathrm{C}$, respectively. The flow rate of carrier gas $\mathrm{N}_{2}$ with a split ratio of $1: 50$ was set at $70 \mathrm{~mL} / \mathrm{min}$. The fatty acids were identified with reference to the retention times of standard fatty acid methyl ester performed at the same conditions.

\subsection{Analysis of Fatty Acid Composition}

The analysis of fatty acid methyl esters was performed on a gas chromatograph (GC) (HP5890) equipped with a flame ionization detector (FID) and a HP-Innowax capillary column (30 $\mathrm{m} \times 0.25 \mu \mathrm{m})$. The column, injector, and detector temperatures were set at 190,230 , and $230{ }^{\circ} \mathrm{C}$, respectively. The flow rate of carrier gas $\mathrm{N}_{2}$ with a split ratio of $1: 50$ was set at $70 \mathrm{~mL} / \mathrm{min}$. The fatty acids were identified with reference to the retention times of standard fatty acid methyl ester performed at the same conditions.

\subsection{Quantitative Analysis of Camellianin A}

$30.8 \mathrm{mg}$ camellianin A was dissolved in methanol to produce stock solution of $0.308 \mathrm{mg} / \mathrm{ml}$. For the calibration curve, the stock solution was diluted with methanol in the concentration range from 0.0154 to 0.308 $\mathrm{mg} / \mathrm{ml}$.

$1.079 \mathrm{~g}$ of dried powdered leaves was placed in a Soxhlet extractor and refluxed at $80{ }^{\circ} \mathrm{C}$ for $10 \mathrm{~h}$ with $150 \mathrm{ml}$ methonal, and then the extract was collected and diluted to $250 \mathrm{ml}$ with methanol for HPLC analysis.

The samples were separated on a reversed phase column, Diamonsil ${ }^{\circledR} \mathrm{C} 18$ column $(4.6 \times 250 \mathrm{~mm} ; 5 \mu \mathrm{m}$ particle size) manufactured by DIKMA. The mobile phase consisted of methanol and water $(1: 1)$ with a flow rate of $0.8 \mathrm{~mL} / \mathrm{min}$. The HPLC system consisted of a Waters 1525 Binary HPLC Pump and a Waters 2487 Dual $\lambda$ Absorbance Detector. The injection volume was $10 \mu \mathrm{L}$ and the wavelength for detection was set at $265 \mathrm{~nm}$. Before HPLC analysis, all samples must be passed through a $0.45 \mu \mathrm{m}$ millipore filter. The quantitative analysis of Camellianin A in the samples was based on an external standard. The chromatographic data were recorded and processed by Breeze System 3.30 software.

\subsection{Statistical analysis}

The data obtained in this study were expressed as the mean of three replicate determinations and standard deviation (SD). Statistical comparisons were carried out using student $t$ test. $\mathrm{P}$ values of $<0.05$ were considered to be significant. 


\section{Results and Discussion}

\subsection{Crude Fat Content and Fatty Acid Composition}

In this study, the crude fat content was determined as $3.48 \%$. The GC analyses of samples were shown in Table 1 . The Adinandra nitida leaves were abundant in unsaturated fatty acids, with only lower amounts present in saturated fatty acids.

The composition rates of unsaturated fatty acids, such as oleic acid (18:1), linoleic acid (18:2), and linolenic acid (18:3) are $7.49 \%, 17.65 \%$, and 31.85\%, respectively. Meanwhile, major saturated fatty acid of Adinandra nitida leaves was palmitic acid (16:0) which comprised approximately $19.87 \%$ of total fatty acids. Accordingly, only small quantity of stearic acid (18:0) was observed.

Polyunsaturated fatty acids such as linoleic acid (18:2), linolenic acid (18:3), and arachidonic acid (20:4) are called essential fatty acids (EFA) because of their necessity in the human body. Linolenic acid is a known enhancer for transporting bioactive compounds into the skin, and it is converted to arachidonic acid which serves as a precursor for powerful hormone-like compounds [4].

\subsection{Crude Protein Content and Amino Acid Composition}

In this study, the crude protein content was determined as $10.51 \%$. It was considered that the high contents of necessary amino acids such as lysine, threonine, valine, methionine, isoleucine, leucine, tryptophane and phenylalanine, will provide a high nutritional value. Because lysine is the first limiting amino acid in the various protein sources, and sulfur containing amino acids are evaluated as the functional are evaluated as the functional amino acids [5].

\subsection{Camellianin A}

Flavonoid, abundant in fruits, teas, vegetables, and medicinal plants, have received the greatest attention and have been investigated extensively, since they are highly effective free radical scavengers and are assumed to be less toxic than synthetic antioxidants such as BHA and BHT, which are suspected of being carcinogenic and causing liver damage [6]. According to our previous study [7], the main flavonoid in leaves of Adinandra nitida was identified as camellianin A (Fig. 1). In this study, the content of camellianin A in Adinandra nitida leaves was determined as $27.57 \pm 0.92 \%$ (Fig. 2). To the best of our knowledge, there are few plant sources containing so much flavonoid like leaves of Adinandra nitida. To this day, more than 4000 kinds of flavonoids have been identified or synthesized, but few of them can be widely used in fields of food, medicine. Why? Though flavonoids ubiquitously exist in plants, few kinds of plants can contain enough flavonoids to achieve large-scale production. In this study, Adinandra nitida leaves were found to be a kind of flavonoid-rich plant source. 
Table 1. Composition of fatty acids in Adinandra nitida leaves

\begin{tabular}{ccccc}
\hline & $\begin{array}{c}\text { Retention } \\
\text { time }(\mathrm{min})\end{array}$ & Fatty acids & $\begin{array}{c}\text { Peak Area } \\
\left(\mathrm{pA}^{*}\right)\end{array}$ & Area ratio $(\%)$ \\
\hline 1 & 21.58 & $\mathrm{C} 13: 0$ & 1184 & 1.27 \\
2 & 25.049 & $\mathrm{C} 15: 0$ & 2241 & 2.41 \\
3 & 25.884 & $\mathrm{C} 15: 1$ & 7499 & 8.1 \\
4 & 26.770 & $\mathrm{C} 16: 0$ & 18450 & 19.87 \\
5 & 31.496 & $\mathrm{C} 18: 0$ & 3622 & 3.9 \\
6 & 33.052 & $\mathrm{C} 18: 1$ & 6953 & 7.49 \\
7 & 34.696 & $\mathrm{C} 18: 2(\mathrm{t})$ & 611 & 0.66 \\
8 & 35.507 & $\mathrm{C} 18: 2(\mathrm{c})$ & 16391 & 17.65 \\
9 & 36.498 & $\mathrm{C} 20: 0$ & 1088 & 1.17 \\
10 & 38.413 & $\mathrm{C} 18: 3$ & 290582 & 31.85 \\
\hline
\end{tabular}

Table 2. Composition of amino acids in Adinandra nitida leaves

\begin{tabular}{cccc}
\hline Free amino acid & $\begin{array}{c}\text { Content } \\
(\mathrm{mg} / 100 \mathrm{~g})\end{array}$ & Free amino acid & $\begin{array}{c}\text { Content } \\
(\mathrm{mg} / 100 \mathrm{~g})\end{array}$ \\
\hline Aspartic acid & 910.96 & Tyrosine & 427.94 \\
Glutamic acid & 915.01 & Valine & 507.36 \\
Serine & 121.52 & Methionine & 151.58 \\
Glycine & 539.92 & Cysteine & 18.02 \\
Histidine & 388.48 & Isoleucine & 408.59 \\
Arginine & 541.73 & Leucine & 129.75 \\
Threonine & 372.96 & Phenylalanine & 470.38 \\
Alanine & 537.11 & Lysine & 482.63 \\
Proline & 523.32 & Tryptophan & 236.37 \\
Total & & 7683.62 & \\
\hline
\end{tabular}
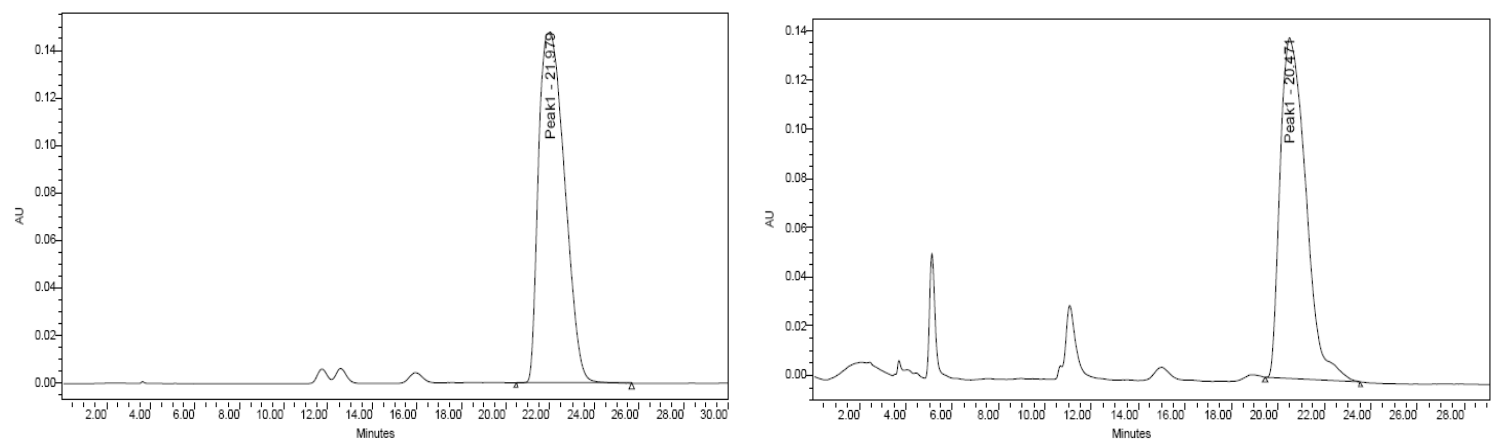

Fig. 1. HPLC profiles of camellianin A and the extract 


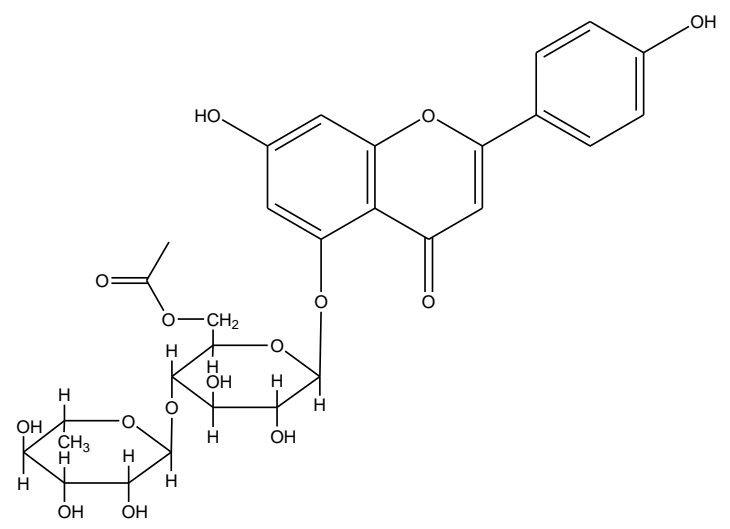

Fig. 1. Chemical structure of camellianin A

\section{Conclusion}

In this study, it was found that Adinandra nitida leaves were rich in necessary amino acids and unsaturated fatty acids. The content of the main flavonoid (camellianin A) was as high as $27.57 \pm 0.92 \%$. These results prove the high nutritional value of Adinandra nitida leaves. It has great commercial interest in the food and phytopharmaceutical market.

\section{References}

[1] E. Yuan, Z. Ning, B. Liu, and J. Xuan, "Research on purification and antioxidant activity of camellianin A from Adinandra nitida leaves," Science and Technology of Food Industry, vol. 29, no. 4, pp. 212-214, April 2008.

[2] B. Liu, Y. Zhan, K. Xu, J. Gao, and Z. Ning, "Identification of flavonoids in leaves of adinandra nitida by HPLC-PDA-ESI/MS," Food Research and Development, vol. 28, no. 3, pp. 118-120, March 2007.

[3] B. Liu, Z. Ning, J. Gao, and K. Xu, "Preparing apigenin from leaves of Adinandra nitida," Food technology and Biotechnology, vol. 46, no. 1, pp. 111-115, March 2008.

[4] S. Kim, S. Kim, and C. Park, "Introduction and nutritional evaluation of buckwheat sprouts as a new vegetable," Food Research International, vol. 37, no. 4, pp. 319-327, May 2004.

[5] A.M. Hamad, and M.L. Field, "Evaluation of protein quality and available of germinated and fermented cereals," Journal of Food Science, vol. 44, no. 2, March 1979.

[6] B. Liu, Y. Zhan, Z. Ning, J. Gao, and K. Xu, "Characterization and antioxidant activity of flavonoid extract from leaves of Adinandra nitida Merr. ex Li," Chemistry and Industry of Forest Products, vol. 28, no. 1, February 2008.

[7] S. Burda, and W. Oleszek, "Antioxidant and antiradical activities of flavonoids," Journal of Agricultural and Food Chemistry, vol. 49, no. 6, pp. 2774-2779, May 2001. 